\title{
Climatic Conditions of the South Part of Valday Hills, Russia, and Their Projected Changes During the 21st Century
}

\author{
O. Desherevskaya ${ }^{*}, 1$, J. Kurbatova ${ }^{2}$ and A. Olchev ${ }^{2}$ \\ ${ }^{I}$ Faculty of Geography, M.V. Lomonosov Moscow State University, Moscow, Russia \\ ${ }^{2}$ A.N. Severtsov Institute of Ecology and Evolution of RAS, Leninsky Prospekt 33, Moscow, Russia
}

\begin{abstract}
Modern climate conditions and their possible future changes in the southern part of Valday Hills, Russia, were analyzed using 40-years of meteorological data observations and global model projections. It was shown that the annual, January and July temperatures in the area increased during the last 40 years by about $0.7^{\circ}, 4.0^{\circ} \mathrm{C}$ and $0.3^{\circ} \mathrm{C}$, respectively. Annual precipitation also increased by about $60 \mathrm{~mm}$. Climate simulations for the period up to 2100 provided by a general circulation model ECHAM5 (MPI Hamburg, Germany) according to B1, A1B and A2 IPCC emission scenarios propose significant changes in meteorological conditions for the study area in the future. The mean annual temperature at the end of the century may rise by $2.2-3.9^{\circ} \mathrm{C}$. Increase of January temperatures under different scenarios can range between 3.3 and $6.7^{\circ} \mathrm{C}$. Projected increase of annual precipitation can reach $105 \mathrm{~mm}$ and it is mainly manifested in growth of winter values.
\end{abstract}

Keywords: Present and future climate changes, climate modeling, IPCC emission scenarios, Valday Hills.

\section{INTRODUCTION}

Analysis of meteorological data during the last $100-150$ years highlights significant changes of global air temperature and precipitation [1]. Over the last 100 years $(1906-2005)$ global mean surface temperatures have raised by $0.74^{\circ} \mathrm{C} \pm$ $0.18^{\circ} \mathrm{C}$. The spatial pattern of global temperature changes is very heterogeneous and the most intensive temperature growth has been observed in high latitude areas. At the same time the temperature changes in tropical areas have been relatively small. The spatial pattern of global land precipitation changes is also very non-uniform. Measurements show that precipitation increased in eastern North and South America, northern Europe and northern and central Asia, while decreasing in the Sahel, southern Africa, the Mediterranean and southern Asia.

Modern global warming is usually attributed to increases in greenhouse gas concentrations in the atmosphere, and especially $\mathrm{CO}_{2}$, as a result of anthropogenic activity (fossil fuel use, deforestation etc.). The largest part of atmospheric $\mathrm{CO}_{2}$ is absorbed by green plants during the process of photosynthesis. Some part of $\mathrm{CO}_{2}$ is returned into the atmosphere because of plant respiration. The vital functions of natural ecosystems depend strongly on environmental and particularly climate conditions and must be investigated by different climatological and ecophysiological methods.

Numerical modeling experiments assuming different greenhouse gases emission into the atmosphere as lower boundary conditions are one of the most important methods used in climatic forecast. To evaluate possible future

\footnotetext{
*Address correspondence to this author at the Faculty of Geography, M.V. Lomonosov Moscow State University, Moscow, Russia; Tel: 89032608305; E-mail: lanie188@mail.ru
}

dynamics of greenhouse gases in the atmosphere the International Panel on Climate Change (IPCC) developed several scenarios of gas emissions that are presented in the Special Report on Emission Scenarios (SRES) for periods up to 2100 [2]. The scenarios are based on alternative versions of human society development. Using different emission scenarios it is possible to make projections of possible future climate conditions both for different geographical regions and for the entire Earth.

Expected future climate changes can have a significant impact on land vegetation cover. To forecast the reaction and sensitivity of different plant associations to global warming it is necessary to assess the effects of climate changes on plants in their specific habitats. It can be expected that the largest vegetation changes can be observed at the boundaries and in transitional zones between different vegetation types (for example, tundra-forest or forest-steppes) in consequence of both northern and southern species position at the border of their natural habitats under one or another limitation factor (temperature or moistening). Particularly, it was already shown that projected climatic changes in the area of the southern taiga forest and bog ecosystems of Central European Russia may result in reduction of proportion of spruce and in increase of proportion of broadleaf species in the forest stands by up to $20-40 \%{ }^{1}$.

The main goal of this study was to summarize and analyze the long-term records of meteorological observations and to evaluate the proposed future climate trends provided by a General Circulation Model ECHAM5 [3] for the area of the south part of Valday Hills in Western Russia.

${ }^{1}$ Olchev A, Novenko E, Desherevskaya O, Krasnorutskaya K, Kurbatova J.
Effects of climatic changes on carbon dioxide and water vapor fluxes of
boreal forest ecosystems in European part of Russia. Environmental boreal forest ecosystems in Europ
Research Letters (4) 2009, in print. 


\section{MODERN CLIMATE CONDITION}

\subsection{Methods}

Present climate conditions and their temporal variations in the south of Valday Hills area were derived using measurements at Fedorovskoe and Ostashkov stations, operational since 1963 and 1961, respectively. To describe the climatic variability of the area over all of the 20th century the meteorological data records from the Velikie Luki station, located closely to the study area and operational since 1881, were also used.

The annual, January and July air temperatures and precipitation totals at $2 \mathrm{~m}$ above the ground were used in the analysis. Monthly and annual mean values were computed for each site for all of the observation period. To analyze the modern trends of climatic data the measuring period was divided into two parts: 1963-1980 and 1981-1999.

Time series analyses were conducted using the moving average method, a prevalent method in climatological analyses [4]. The method makes it possible to discern the long-term oscillations of climatic variables and to exclude short-term ones. The 5-years smoothed series were approximated by the second-order polynomial function to clarify the main trends and to predict their future changes.

To analyze experimental data the following statistical parameters were calculated: mean air temperature $\bar{T}$ and precipitation $\bar{P}$, standard deviations $\sigma$, coefficients of skewness $A s$ and coefficients of excess $E x$ (Tables $\mathbf{2}$ and $\mathbf{3}$ ).

\subsection{Site Characteristics}

Meteorological station Fedorovskoe $\left(56^{\circ} 30^{\prime} \mathrm{N}, 32^{\circ} 50^{\prime} \mathrm{E}\right)$ is located in the south part of Valday Hills in the Central Forest State Biosphere Natural Reserve at the watershed of Zapadnaya Dvina (Daugava) and Volga. The territory of the Reserve is faintly hilly and waterlogged plain, covered with natural spruce and small-leaved forests and bogs. The elevation of Fedorovskoe station is $240 \mathrm{~m}$ above sea level.

The Ostashkov station is situated at the southern coast of Seliger Lake at $217 \mathrm{~m}$ above sea level, about $75 \mathrm{~km}$ to the north of Fedorovskoe. The lakes influence on Ostashkov's climate is mainly manifested in higher air temperatures during August-October than in comparison to Fedorovskoe.

The last station, Velikie Luki, is located about $175 \mathrm{~km}$ west of Fedorovskoe at Zapadnaja Dvina tributary. The elevation at Velikie Luki is $99 \mathrm{~m}$ above sea level. The area around this site is relatively flat and mostly deforested.

Comparisons of available meteorological data show that the air temperature in Velikie Luki is a little higher throughout the year than in both Fedorovskoe and Ostashkov (Fig. 1). Distinction of monthly mean air temperature between Fedorovskoe and Velikie Luki is about $0.6{ }^{\circ} \mathrm{C}$ in July and $1.6^{\circ} \mathrm{C}$ in January. It may be explained certainly by both geographical location and altitude difference between both sites. Mean gradient $\left(0.79^{\circ} \mathrm{C} / 100 \mathrm{~m}\right)$ between the stations is rather less than the moist-adiabatic lapse rate. Winter temperature variability (up to $4.5^{\circ} \mathrm{C}$ in January) at all stations considerably exceeds the summer variability $\left(1.1^{\circ} \mathrm{C}\right.$ $\left.-1.5^{\circ} \mathrm{C}\right)$.

Both monthly and annual precipitation rates are larger by about $15 \%$ in Fedorovskoe than in Ostashkov or Velikie Luki. It can be explained very likely by overwetting of the surrounding territory and by large areas covered by forests and bogs around Fedorovskoe. For all stations the interannual variability of precipitation is very high (standard deviations reach $40-60 \%$ of mean values).

\subsection{Modern Temperature and Precipitation Dynamic}

\subsubsection{Observed Temperature Trends}

Analysis of data for Fedorovskoe and Ostashkov stations shows a gradual increase of January and annual temperatures for the period from 1961 to 2006. An increase in July temperature is clearly manifested only since the nineties (Fig. 2).

The 40-year increase of January temperatures in Fedorovskoe and Ostashkov was about $3.9^{\circ} \mathrm{C}$ and $4.2^{\circ} \mathrm{C}$ with standard deviation of $4.0^{\circ} \mathrm{C}$ and $3.7^{\circ} \mathrm{C}$, respectively (Table 1). For Ostashkov station this growth is statistically significant, however, at the end of 20th century it does not exceed $2 \sigma$. Analysis of longer time series for Fedorovskoe station (until 2006) reveals also statistical significance of

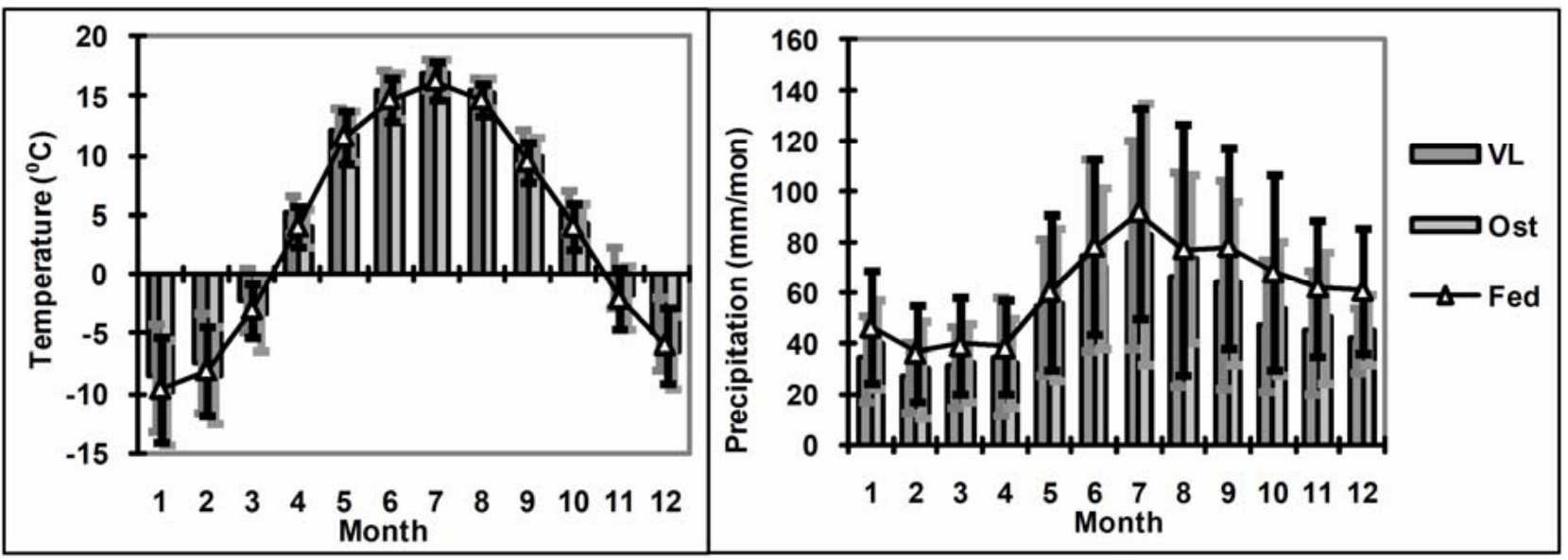

Fig. (1). Comparison of monthly mean temperature, precipitation rates and their standard deviations in Fedorovskoe (Fed), Ostashkov (Ost) and Velikie Luki (VL) stations. 


\section{a) January}

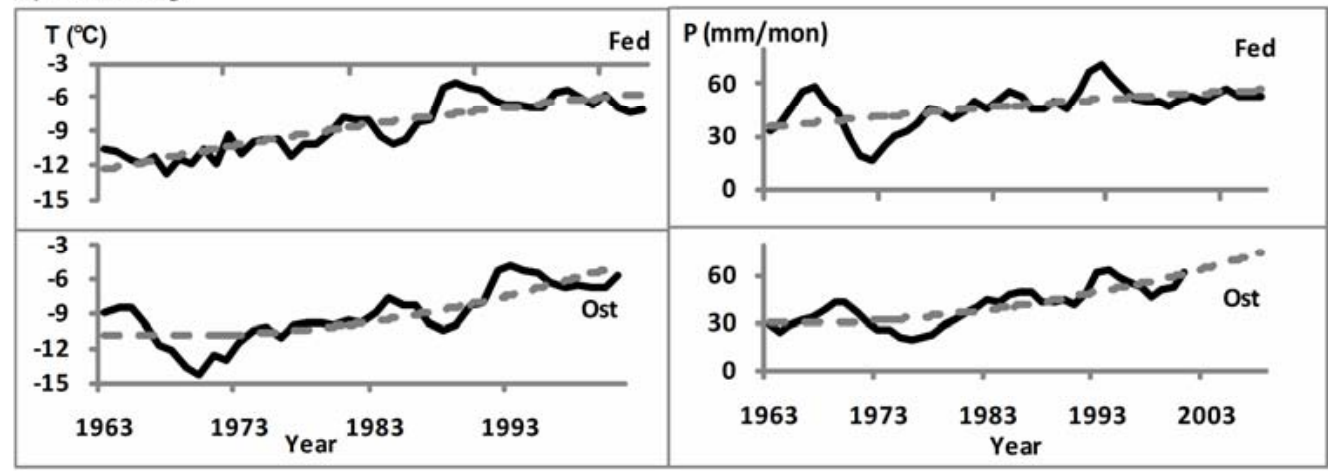

\section{b) July}

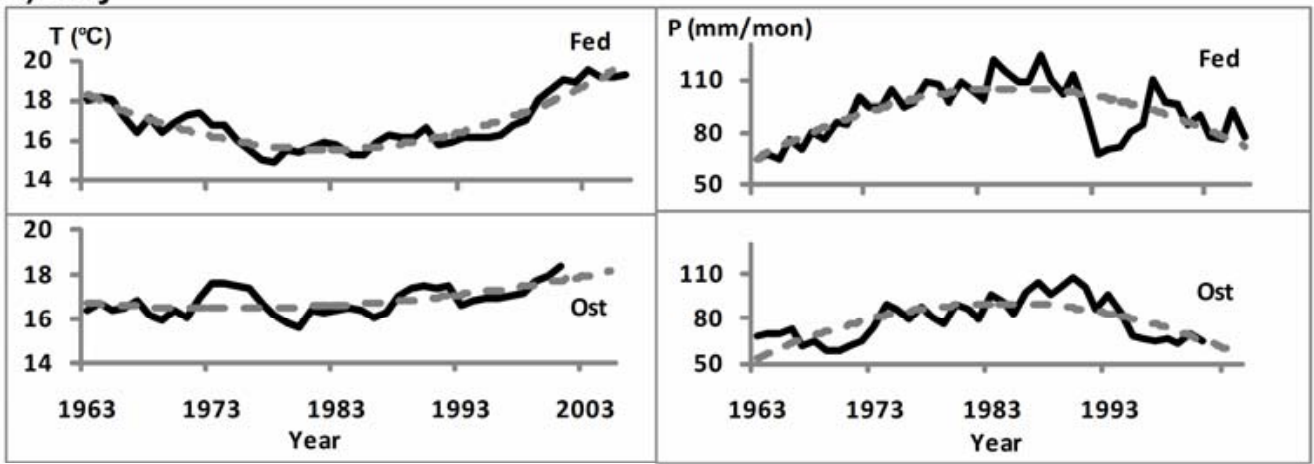

\section{c) Year}

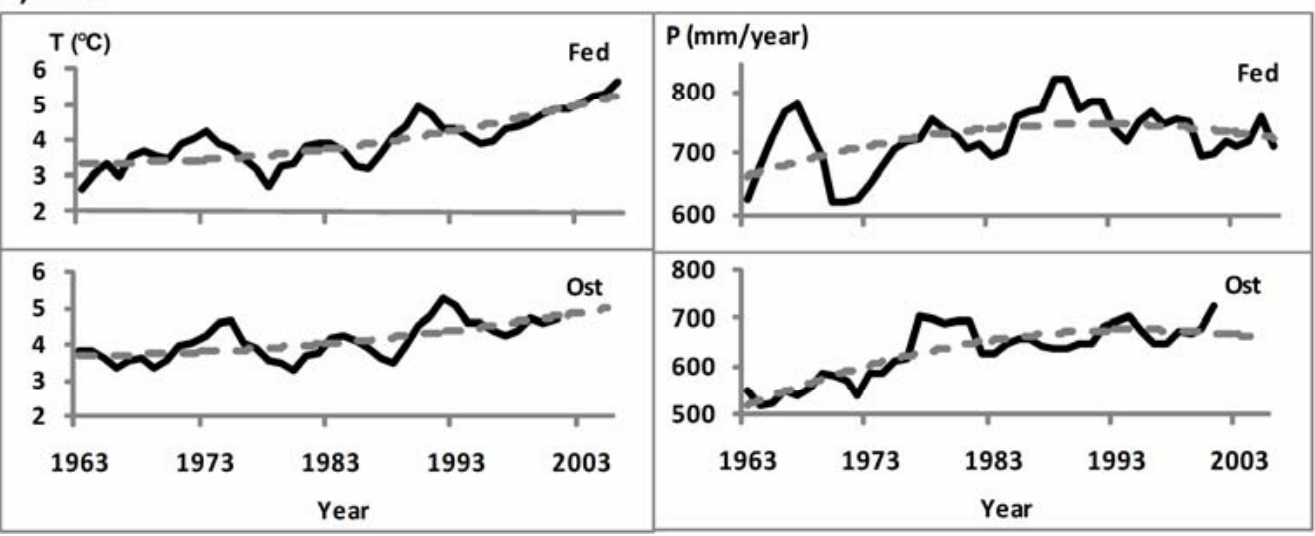

Fig. (2). Interannual patterns of January (a), July (b) and annual (c) values of air temperature (left) and precipitation (right) in the south part of Valday Hills (stations Fedorovskoe, Fed, and Ostashkov, Ost).

January warming. Mean annual temperature at both sites increased by $0.7^{\circ} \mathrm{C}$ for the period from 1963 to 1999 with $\sigma=1{ }^{\circ} \mathrm{C}$. Taking into account the present trend of climatic changes the oscillations of mean annual temperature in the southern part of Valday Hills may overstep the limits of modern variability in the first or second decades of the $21 \mathrm{st}$ century. This hypothesis agrees well with results of climate modeling for the 21 st century and will be discussed in the following sections.

Values of $A s$ and $E x$ coefficients calculated for temperature time series show a drastic increase in the number of years with temperatures above climatic mean values (left asymmetry). Moreover, the peakedness of its distribution is also heightened (excess increases). For such distributions an increase of extreme values is typical, and outermost values transgress the bounds of $\pm 3 \sigma$ more often then in a normal case.

The statistical significance of an increase in January temperature at Fedorovskoe was evaluated by Student $\tau$ test for homogeneity of two time series (1963-1980 and 19811999) of mean $\bar{T}_{\text {1Jan и }} \bar{T}_{\text {2Jan values. Calculations revealed }}$ that the empirical value exceed the theoretical one $\tau_{\text {emp }}=2.88>\tau_{\text {theor }}=2.44$ with $1 \%$ significance level $(\alpha=1 \%)$ and number of degrees of freedom $\left(l_{1}+l_{2}-2\right)$ is equal to 35 (where $l_{1}$ and $l_{2}$ are the duration of corresponding series). Consequently, suggested hypothesis about homogeneity of the two series is inapplicable (and $\bar{T}_{1 \mathrm{Jan}}<\bar{T}_{2 \mathrm{Jan}}$ ). 
Table 1. Statistics of Long-Term Dynamics of Air Temperature ( $\bar{T}$ ) in Fedorovskoe (Fed) and Ostashkov (Ost)

\begin{tabular}{|c|c|c|c|c|c|c|c|c|c|}
\hline Period & Site & \multicolumn{4}{|c|}{ 1963-1980 } & \multicolumn{4}{|c|}{ 1981-1999 } \\
\hline January & Ost & -11.4 & 3.4 & 0.1 & -0.6 & -7.2 & 4.0 & -1.8 & 3.8 \\
\hline July & Fed & 16.5 & 1.9 & 0.5 & -1.0 & 16.5 & 1.2 & 0.9 & 0.2 \\
\hline \multirow{2}{*}{ Year } & Fed & 3.4 & 1.1 & -0.7 & -0.1 & 4.1 & 1.0 & -0.4 & 0.5 \\
\hline & Ost & 3.7 & 0.9 & 0.4 & -0.1 & 4.4 & 1.0 & -0.2 & -0.1 \\
\hline
\end{tabular}

\subsubsection{Observed Precipitation Trends}

Whereas the January precipitation rates for Ostashkov and Fedorovskoe stations increased gradually from 1961 to 2006, July precipitation increased prior to the mid eighties and decreased slightly afterward (Table 2). Annual precipitation increased before the middle of the eighties and did not change significantly afterward.

Estimated increases of January precipitation in Fedorovskoe and Ostashkov were $16 \mathrm{~mm}$ and $21 \mathrm{~mm}$ whereas increases of July precipitation were much smaller ( 7 and $8 \mathrm{~mm}$, respectively). The faster increase of January and July precipitation rates in Ostashkov is probably connected with local climatic conditions.

\section{FUTURE CLIMATE CONDITION}

\subsection{Methods}

To forecast the future climate in the south part of Valday Hills for the period 2000-2100 the results of numerical experiments provided by the general atmospheric and ocean circulation ECHAM5 model (Max-Plank Institute, Hamburg, Germany) were used [3]. The ECHAM5 model is based on hydro-thermodynamic equations and employs a spectral-grid approach. Our study used one month time steps when examining both the reanalysis data (1973-1999) and the predicted future trends (2000-2100).

To describe accurately the possible future patterns of meteorological parameters in the first step it is necessary to know how well the General Circulation Models (GCM) reproduced the modern climate conditions. For this purposes the temperature and precipitation reanalysis of 15 SRES models for the European Part of Russia (EPR) was evaluated [5]. Model reanalysis data as well as experimental data for the period 1961-1989 interpolated to the regular grid were used for model accuracy assessment. It should be taken into consideration that almost all ensemble of available climate models noticeably underestimate the winter temperatures (by $4-8^{\circ} \mathrm{C}$ for the centre of EPR), and slightly underestimate summer ones (by $1-2^{\circ} \mathrm{C}$, respectively). Winter and autumn precipitation is overestimated (by about 10-20 $\mathrm{mm} \mathrm{month}^{-1}$ ) by majority of the models, summer precipitation rates are slightly underestimated (by $5-10 \mathrm{~mm} \mathrm{month}^{-1}$ ). Annual precipitation was also overestimated by majority of considered models.

In comparison to other SRES ensemble models the ECHAM5 model reproduced temperature dynamics very faithfully (ECHAM5 has the second range after CCSM3 model, NCAR, USA) and it was in the middle position in the range of quality of precipitation reproduction. It is mainly cased by overestimation of annual rainfall for the center of EPR.

The possible climate change may be easily evaluated as a difference between future and modern climatic parameters. Question of whether the estimator is biased for both modern and future climates (in that case the mean error will smooth) or whether it varies depending on conditions is open for discussion.

Table 2. Statistical Parameters of Precipitation ( $\bar{P}$ ) Observations in Fedorovskoe (Fed) and Ostashkov (Ost)

\begin{tabular}{|c|c|c|c|c|c|c|c|c|c|}
\hline \multirow{2}{*}{ Period } & \multirow{2}{*}{ Site } & \multicolumn{4}{|c|}{ 1963-1980 } & \multicolumn{4}{|c|}{ 1981-1999 } \\
\hline & & $\bar{P}$ & $\sigma$ & As & $E x$ & $\bar{P}$ & $\sigma$ & $A s$ & $E x$ \\
\hline \multirow{2}{*}{ January } & Fed & 38 & 23 & 0.4 & -1.1 & 54 & 19 & -0.2 & -0.4 \\
\hline & Ost & 30 & 15 & 0.2 & -0.6 & 51 & 18 & 0.0 & 0.1 \\
\hline \multirow{2}{*}{ July } & Fed & 89 & 34 & 0.5 & -1.2 & 96 & 52 & 0.2 & -0.8 \\
\hline & Ost & 75 & 27 & 0.4 & -0.6 & 83 & 45 & 0.1 & -1.0 \\
\hline \multirow{2}{*}{ Year } & Fed & 698 & 111 & 0.2 & -0.5 & 752 & 88 & 0.8 & 0.2 \\
\hline & Ost & 601 & 119 & 0.4 & 0.7 & 665 & 82 & -0.3 & 1.8 \\
\hline
\end{tabular}


Obviously, a general circulation model produces statistical and not distinct forecasts of meteorological parameters for the period up to 2100. A series of experiments with small deviations of initial conditions show that some years in future (e.g. 2090) may be either very warm and wet or cold and dry. Nevertheless the climate change may be assessed by a long-period average (20-30 years). For better evaluation of mean values the averaging of several numerical experiments with small deviations in initial conditions was used. Annual variation must be assessed using single experiments.

According to [5] to make correct analysis of climatic trends the analysis of space averaged data covering about 1015 model cells have to be used. However, taking into account that only $9(3 \times 3)$ cells cover the area about $625 \mathrm{~km}$ the use of such averaging makes obviously very difficult an interpretation of local climate variability. In our study we used compromised approach based on averaging of 6 cells located closely to Valday Hills.

Three IPCC scenarios of future climate conditions - B1, $\mathrm{A} 1 \mathrm{~B}$ and A2 - were considered in our study. B1 is a sustainable development scenario with high level of environmental and social consciousness and rapid technological change, which expresses in comparatively low level of greenhouse gases emission. A1B scenario is a case of rapid and successful global economic development with a balance between technology improvements and resource assumptions such that no single source of energy is overly dominant. A1B is temperate, medium emission level scenario. A2 represents an uneven differentiated world with relatively slow technology innovation and diffusion and rapid growth of population with high greenhouse gases concentration as a result.

\subsection{Future Temperature Trends}

According to results of climate projections the January temperatures in the Valday Hills region in the 21st century may increase by $3.3-6.7^{\circ} \mathrm{C}$ depending on the emission scenario (Fig. 3, Table 3). Increase of July and annual temperatures is somewhat lower and does not exceed $2.3^{\circ} \mathrm{C}$ and $3.9^{\circ} \mathrm{C}$ respectively. No significant changes in projected interannual temperature variability have been indicated. The projected temperature increase is not monotonous. According to model projections the annual and January temperatures in 2000-2030 will increase quite slowly. In the first third of the 21 st century the annual temperature will not exceed temperatures of the warmest years 1990-2006. At the same time the frequency of very cold winters will decrease. During 2030-2070 a smooth rise in annual temperature up to $6-7^{\circ}$ is foresight. The temperature increase quickens in 20702090 (annual temperature run up to the highest in 21st century values of $8-9^{\circ} \mathrm{C}$ ). The slight decrease of temperature values at the end of the century under A1B scenario is also predicted.

Projected annual and January temperatures under the A2 scenario with 'the highest greenhouse gases concentration' does not constantly exceed values of another scenarios during entire 21 st century. E.g., temperature in 'medium' A1B scenario using 20 -year average series exceeds projected temperature in A2 scenario by $0.5-1^{\circ} \mathrm{C}$ during $2020-2050$. Annual temperature under the $\mathrm{B} 1$ scenario is lower than under others scenarios during the second half of the $21 \mathrm{st}$ century. At the end of the century the differences of January and annual temperatures between $\mathrm{A} 2$ and $\mathrm{B} 1$ scenarios amounts to $3^{\circ} \mathrm{C}$ and $1.5^{\circ} \mathrm{C}$, respectively.

It is obvious that proposed global warming can have significant impact on structure and functioning of land surface vegetation and especially on forest ecosystems. The

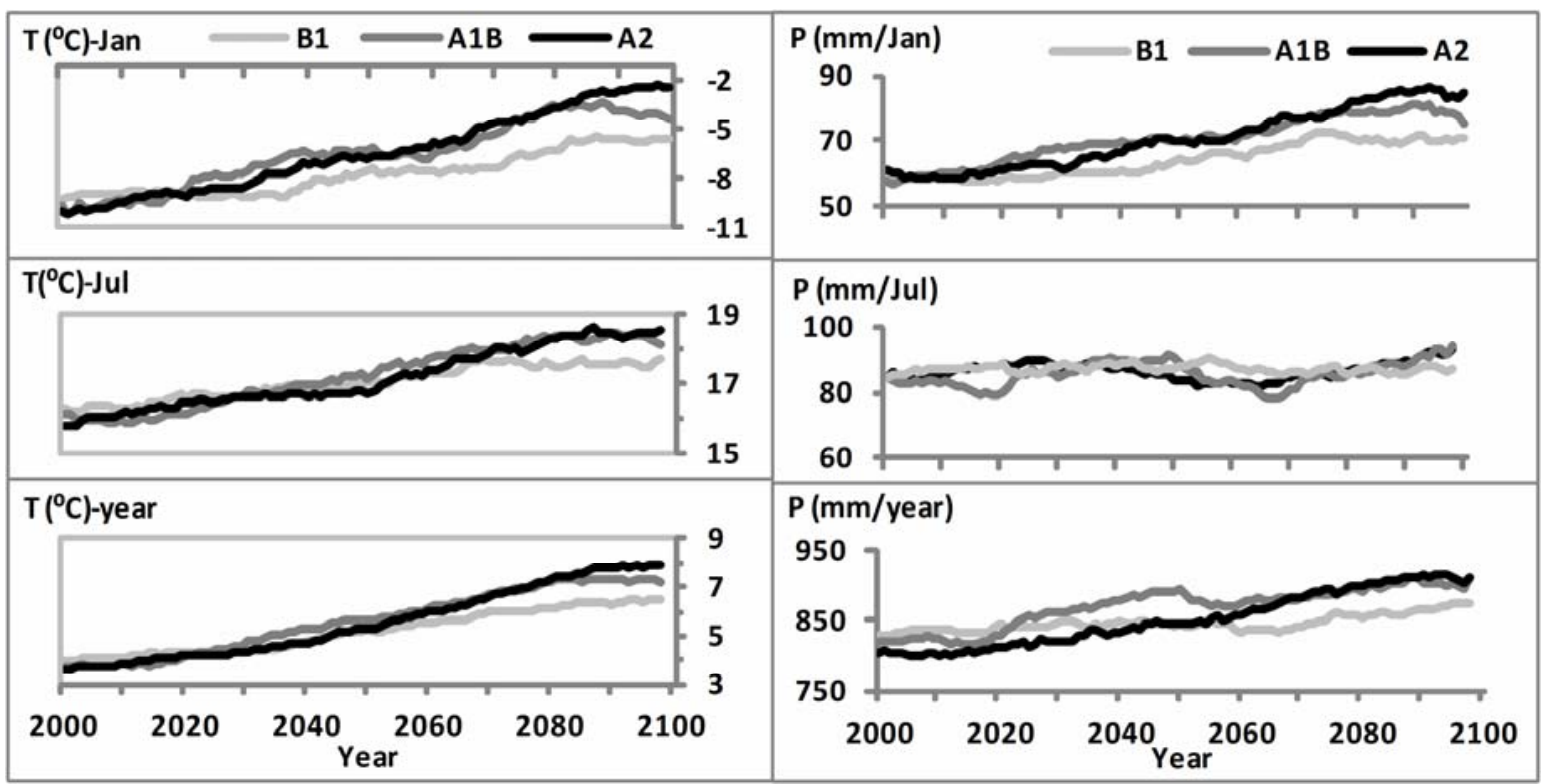

Fig. (3). Future changes of mean annual temperature (left) and precipitation rates (right) for the period from 2000 to 2100 predicted by ECHAM5 model according to IPCC B1, A1B and A2 scenarios in January (the upper graph), July (in the middle) and for all year (in the bottom) for the southern part of Valday hills. Temperature and precipitation series were smoothed by 20 -and 30 -year averaging procedure, respectively. 
Table 3. Projected Changes of Temperature $(\bar{T})$ and Precipitation $(\bar{P})$ in the Southern Part of the Valday Hill Area for the Next 100-Years Under Different Climatic Scenarios

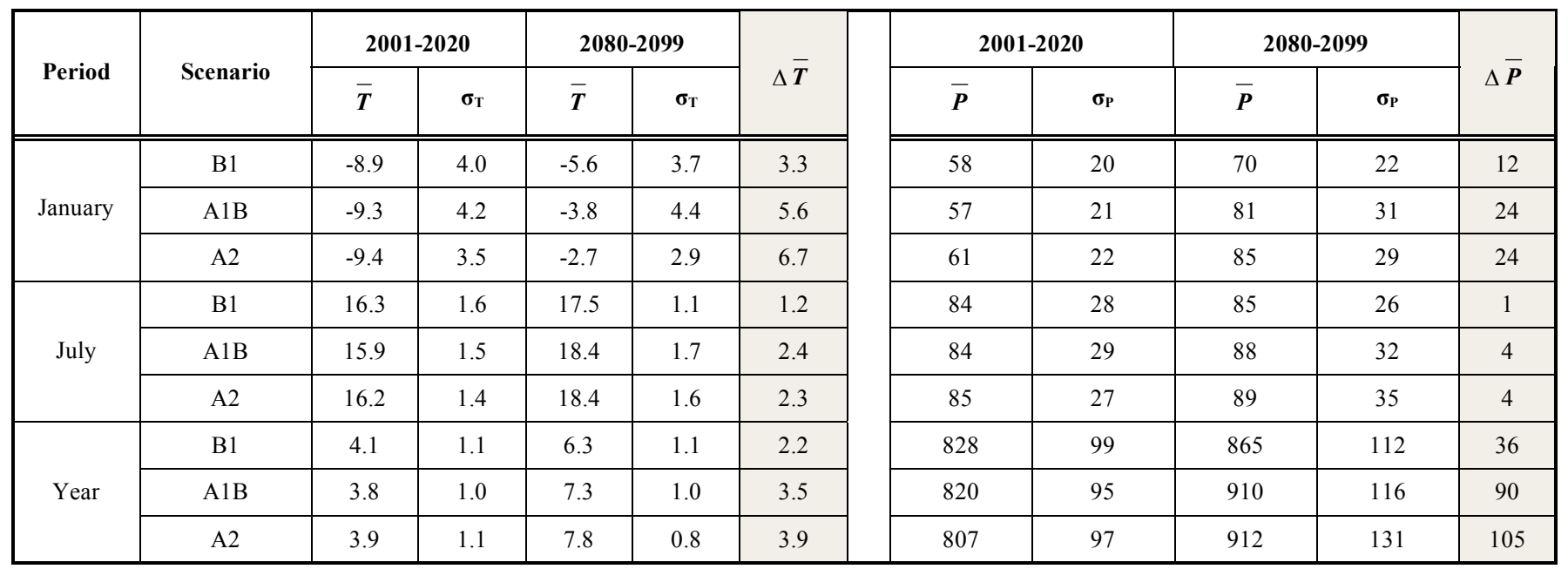

results of paleo-environmental reconstructions for the area of the CFSNBR [6] showed that, for example, in the Late Atlantic optimum $\left(4500-4800{ }^{14} \mathrm{C}\right.$ years BP) of the Holocene mean annual temperature exceed present values by $1{ }^{\circ} \mathrm{C}$. Such conditions are projected to be in 2020-2030. The vegetation during that time was represented by a larger proportion of broadleaf species in the forest stands. Taking into account that the rate of modern and projected climatic changes significantly exceeds any changes that have been reconstructed for, for example, the last interglacial period, it can be expected that the response of vegetation to future climate changes can be differed from the responses observed in the past epochs. All relationships observed in system "vegetation-atmosphere" must be very accurately investigated using different modeling or experimental approaches.

\subsection{Future Precipitation Trends}

All modeling experiments under all scenarios propose an increase of annual rainfall for our study area for the period up to 2100. The increase in precipitation rates is almost linearly correlated with the increase of air temperature. Under A2 scenario characterized by 'the most intensive warming' (highest greenhouse gases concentration) precipitation increases by $105 \mathrm{~mm}$, under A1B - by $90 \mathrm{~mm}$ and under B1 - by only $36 \mathrm{~mm}$ at the end of the 21 st century comparing with present conditions. Only for the A2 scenario did the projected growth of annual precipitation exceed limits of modern precipitation variability. Maximal precipitation increase is proposed for winter period. There is no clear trend in precipitation during the summer. Projected increase of snow amount may result in improvement of plant hibernation conditions and in an increase of soil water capacity in spring.

\section{CONCLUSION}

Modern climate dynamics in the southern part of Valday Hills is characterized by a significant increase of air temperature (in January by $3.9^{\circ} \mathrm{C}-4.2^{\circ} \mathrm{C}$ ) and precipitation (annual rates by 54-64 $\mathrm{mm}$ ) for the entire period of measurements from 1963 to 1999. Annual temperature growth was equal to $0.7^{\circ} \mathrm{C}$ between $1963-1999$ and still less than its annual variability $\left(\sigma=1^{\circ} \mathrm{C}\right)$. These trends are also well expressed in model climate predictions for the 21 st century provided by the general circulation model ECHAM5. Depending on climate scenario the proposed increase in annual temperature ranges between 2.2 and $3.9^{\circ} \mathrm{C}$, with increases in annual precipitation between 36 and $105 \mathrm{~mm}$. winter months are characterized by the most intensive increases (about $3.3-6.7^{\circ} \mathrm{C}$ and $12-24 \mathrm{~mm} \mathrm{month}^{-1}$ in January). The projected annual courses are more smoothing and climate becomes more temperate. One of the reasons of such tendency is probably an increase of latitudinal circulation and western transfer intensification in Central European part of Russia.

The projected climate conditions will obviously result in some changes of vegetation structure and functioning. Modern climatic changes are occurring very rapidly and understanding the response of different ecosystems to changing climatic conditions will require further complex and sophisticated experimental and theoretical investigations.

\section{ACKNOWLEDGEMENTS}

This study was supported by a grant from the Russian Foundation for Basic Research (RFBR 08-04-01254-a). We are very thankful the board and research scientists of the Central Forest State Biosphere Natural Reserve for help with meteorological data and result interpretation.

\section{REFERENCES}

[1] IPCC Climate Change. The physical science basis. Contribution of working group I to the fourth assessment report of the IPCC. Cambridge University Press 2007.

[2] IPCC Special Report on Emission Scenarios. Cambridge University Press 2000.

[3] Roeckner E, Bäuml G, Bonaventura L, et al. The atmospheric general circulation model ECHAM 5. PART I: model description, Report 349. Hamburg: Max-Planck Institute for Meteorology 2003. 
[4] Isaev A. Statistics in meteorology and climatology. Moscow University Press 1988.

[5] Kislov A, Evstigneev V, Malkhazova S, et al. The forecast of climatic resources of the East European Plain under XXI century warming. Moskov: Max Press 2008.
[6] Novenko EY, Olchev A, Desherevskaya O et al. Paleoclimatic reconstructions for the south of Valdai Hills (European Russia) as paleo-analogues of possible regional vegetation changes under global warming. Environ Res Lett 2009; 4(045016): 7.

(C) Desherevskaya et al.; Licensee Bentham Open.

This is an open access article licensed under the terms of the Creative Commons Attribution Non-Commercial License (http://creativecommons.org/licenses/by$\mathrm{nc} / 3.0 /$ ) which permits unrestricted, non-commercial use, distribution and reproduction in any medium, provided the work is properly cited. 